\section{SCIENCE AND ENGINEERING.}

$A T$ a meeting of the Junior Institution of Engineers on November ${ }_{15}$, Sir J. J. Thomson, F.R.S., president of the association, delivered an address on the relations between pure science and engineering. The distinction between them, he said, is one of aim, not of method. The methods employed by the physicist and the qualities of mind called into play in his investigations are to a large extent the same as those used by the engineer in the higher branches of engineering. It is not the business of the physicist in his researches to concern himself at all with utility. Almost every advance in pure physics has been turned to account by the engineer, the manufacturer, or the doctor. But nothing would be more disastrous to the progress of engineering than that the workers in pure science should hamper themselves by considerations as to the utility of their work, or confine their attention to points which have an obvious practical application.

The province of engineering is to survey the facts known to science, and to select those which seem to have in them the possibilities of industrial application, and then to study and develop them from this point of view. This can often best be done in laboratories attached to works engaged in active trade. The success of works' laboratories in Germany and the United States, and to a growing extent in this country, is one of the most striking features in modern industrial development. A closer connection with pure science would be of the greatest service to engineering and commerce in this country, and though strides have been made in this direction in recent years, Sir J. J. Thomson pointed out we are still behind Germany in the importance we attach to pure science and in the eagerness with which new discoveries are applied to industrial purposes. As an instance, to judge from the number of "Thermos flasks" met with, the manufacture of these flasks must constitute a large and profitable business. It is said, however, that none of these flasks is made in England. Yet the Thermos flask is an English invention, being nothing but what is known to physicists as the "Dewar vessel," which was invented by Sir James Dewar for the purpose of storing liquid air without evaporation, and was described by him some vears aso. Although the discovery was made and first published in England, no English manufacturer took it up, but left it to foreign rivals to make it the basis of an important trade.

It is, he continued, the obiect of applied science to keep theory and practice at the same level. Theory and practice do better work when they are driven abreast rather than in tandem. The more intimate the relation between the workers in pure science and those engaged in the application of science, the greater will be the opportunities of deepening the faith in science of the practical man. Faith in the results of pure science is more robust in Germany and the United States than in this country; here we cultivate more exclusively things which ripen quickly and yield an immediate return upon the capital invested, and are inclined to turn aside from projects which, though more profitable in the long run, will, so to speak, take a long time before they come into bearing.

\section{ZOOLOGY IN THE INDIAN EMPIRE.}

TO the September number of Spolia Zeylanica Prof. Punnett contributes an important paper, illustrated by two double coloured plates, on mimicry in Ceylon butterflies, with a suggestion as to the nature of polymorphism. After giving a list of the hitherto recorded instances, which are relatively numerous in comparison with the extent of the fauna, the author points out that this mimicry is far less striking among the living insects than in museum specimens. Not only is this difference apparent on the under surface of the wings when the insects are at rest, but it is still more noticeable in the mode of flight, so that with very little experience the eye learns to distinguish between the mimic and the mimicked. In the well-known case of Papilio polyotes, with its three phases of females, one of which closely resembles the male of the same species, while the second mimics the male of $\cdot P$. aristolochiae, and the third that of $P$. hectorboth the two latter being inedible, while the first is edible -the author observes " that though model and mimic may be readily distinguished at rest, whether with wings expanded or closed, yet the resemblance between them may be sufficient to deceive such enemies as attack them when flying. Such, however, is certainly not the case. The mode of flight of $P$. polyotes is similar for all three forms, and is totally distinct from that of $P$. hector and $P$. aristolochiae.

After referring to the distribution of the three species and the relative numbers of the males and females of the different forms in various localities, the author states that the facts " are far from lending support to the view that the polymorphic females of $P$. polyotes have owed their origin to natural selection in the way that the upholders of the theory of mimicry would have us believe.'

For Prof. Punnett's suggestion as to the origin of polymorphic females our readers may be referred to the original paper, as it is too long to quote, but it may be mentioned that Mendelism plays a part in the explanation. Mimicry in other species, together with the natural enemies of butterflies in Ceylon, is likewise discussed.

In the same issue Mr. George Duncker, after mentioning that although the group is common in the fresh waters of India and East Africa, none has been hitherto recorded from those of Ceylon, states that during the summer of I 909 he succeeded in obtaining examples of four speciesone of which is new-of pipe-fishes of the family Syngnathida from the rivers of that island.

With the exception of one devoted to a South African frog allied to Rana corrugata of Ceylon, the articles in part iii. of the fifth volume of the Records of the Indian Museum deal with invertebrates of various groups. Among these papers is one by Dr. Annandale on a new genus of psychodid Diptera from the Himalaya and Travancore, based on a minute species from Darijiling, described earlier in the present year by Dr. Annandale as Diplonema superstes; this now becomes Brunettia superstes, while the new Travancore species is to be known as $B$. travancorica. In a second paper the same writer discusses the Indian scalpelloid barnacles of the subsenus Smilium, while in a third $\mathrm{Mr}$. S. Kemp describes three new Indian species of the marine decapod senus Gennadas. Most interesting of all is an article by $\mathrm{Mr}$. C. A. Pavia on the larvæ of a common Calcutta mosquito, known as Toxorhynchites immisericors. It was suspected that these larvæ feed on the larvæ of another mosquito, Stegomyia fasciata, frequently found in water contained in earthen vessels, and experiment has proved the surmise to be true. The larva of $T$. immisericors feed, in fact, greedily on those of Stegomyia, " and as S. fasciata, the yellow-fever mosquito, is very common in earthern pots round Calcutta, one is iustified in assuming that $T$. immisericors plays an important part in its destruction, in a manner which would be of great moment in the event of yellow fever being introduced into the country." R. L.

\section{THE ARRIVAL OF MAN IN BRITAIN.1}

$\mathrm{THE}$ address dealt with the antiquity of man as revealed in the geological record, and with the conditions under which Palæolithic man arrived in Britain. In the Tertiary period the higher (Eutherian) Mammalia appear, en pleine évolution, and afford the means of classifying it into the following well-marked divisions:-(I) The Eocene, in which living families and orders appear and there are no living genera. (2) The Miocene, in which there are living genera and no living species. (3) The Pliocene, in which the extinct species are preponderant and living species appear. (4) The Pleistocene, in which the living species are preponderant, and the extinct are few in number; Palæolithic man appears. (5) The Prehistoric, in which there are no extinct species of land Mammalia, and man is in the stages of culture marked by the use of Neolithic, bronze, and prehistoric iron implements. (6) The Historic period, in which the events are recorded in historv.

In this classification the evolution of the Tertiary Mammalia takes the shape of a genealogical tree with

1 Abstract of the Huxley Memnrial Jecture relivered before the Roval Anthrorological Institute on November 22 by Prof. W. Poyd Daukins, F.R.S.

NO. 2 I 43 , VOL. 85] 